\title{
Correction to: Evaluation of hydroxyapatite/poly(acrylamide-acrylic acid) for sorptive removal of strontium ions from aqueous solution
}

\section{Hisham Soliman Hassan ${ }^{1}$ • Ahmed Mohamed El-Kamash ${ }^{1} \cdot$ Haneen Abdel-Salam Ibrahim ${ }^{1}$}

Published online: 21 December 2019

(C) Springer-Verlag GmbH Germany, part of Springer Nature 2019

Correction to: Environmental Science and Pollution Research (2019) 26:25641-25655 https://doi.org/10.1007//11356-019-05755-1

The original publication of this paper contains a mistake.

The affiliation was missing in the printed version.

Publisher's Note Springer Nature remains neutral with regard to jurisdictional claims in published maps and institutional affiliations.

The online version of the original article can be found at https://doi.org/ 10.1007/s11356-019-05755-1

Haneen Abdel-Salam Ibrahim

haneenabi@yahoo.com

Hisham Soliman Hassan

hisoliman2000@yahoo.com

Ahmed Mohamed El-Kamash

kamash20@yahoo.com

1 Hot Laboratories and Waste Management Center, Atomic Energy

Authority, Cairo 13759, Egypt 